\title{
THE ANALYSIS OF FINISHING TOOLING INFLUENCE ON CORROSION PROPERTIES RESEARCHED BY POTENTIODYNAMIC METHOD
}

\author{
Wojciech Labuda, Adam Charchalis \\ Gdynia Maritime University, The Faculty of Marine Engineering \\ Morska Street 83, 81-225 Gdynia \\ tel.: +48586901549, fax: +48586901399 \\ e-mail:wlabuda@am.gdynia.pl,achar@am.gdynia.pl
}

\begin{abstract}
Angular momentum pumps are very often applied onboard ships. These pumps are used in cooling circuits of medium and high power engines, power plant boilers and in bilge, ballast and fire installations. Very extensive use of angular momentum pumps on board is connected with their numerous advantages. During operation the wear of marine hull, the rotor and shaft seals take place. The research attempts to increase the service life of shafts.

The article presents the research results referring to the analysis of the influence of finish treatment (lathing, grinding and burnishing) on the corrosion properties of steel applied to marine pump shafts. The research was performed on a roller of $40 \mathrm{~mm}$ in diameter made of X5CrNi 18-10 (AISI 304 L) stainless steel.

The lathing process was carried out by means of a WNMG WF 080408 Sandvik Coromant cutting tool with replaceable inserts. The grinding process was performed by grinding attachment for lathes. The $1-80 \times 10 \times 32-99 \mathrm{C}$ 80-N V grinding wheel was used for the process. The process of burnishing was done by SRMD burnisher by Yamato. In addition, the influence of the burnisher passes number on the corrosion properties was determined.

The paper will present the results of potentiodynamic research. To conduct the survey the Atlas 0531 EU \& IA potentiostat will be used. Determination of parameters of the corrosion process will be executed on Elfit 2 computer program.
\end{abstract}

Keywords: plastic tooling, burnishing, surface layers, angular momentum pump, corrosion properties

\section{Introduction}

Vessels and warships are equipped with main propulsion engines, generating sets and auxiliary machinery, which are used in the engine room as well as on deck. Seawater pumps belong to a group of centrifugal angular momentum pumps. Their wide application on board vessels is related to their numerous advantages, which comprise simple construction, good performance characteristic, easy adjustment, quiet work and the possibility of applying direct electric motor drive. Centrifugal angular momentum pumps are utilized in the cooling system of high and medium speed engines, for supplying boilers, in bilge systems, ballast systems and in firefighting installations. During their service, the wear of pump body, rotor, sealing and shaft takes place. The research work made an effort to improve the shafts service durability and was based on carrying out tests for contact fatigue, friction wear and electrochemical corrosion.

Due to hard service conditions, marine pumps working in seawater environment are made of corrosion resistant materials. In spite of the fact that pump shafts are made of an expensive material, it is not possible to avoid service damage. This damage includes cracking, plastic deformation, excessive wear of pins in places of mounting rotor discs and sealing chokes, corrosive wear, friction wear, erosive wear and splineways knock outs. During service experience, the most common problem that is observed is excessive wear of pins causing their diameter decrease as well as exceeding the permissible shape deviations in place of chokes mounting.

Technology used in production process has a vital influence on the reliability and service life of machine parts. The final formation of surface layer, that is the dimensions and service properties, is achieved during finish treatment of a given element. The basic methods of final tooling of shafts include precise lathing, grinding or burnishing operation. 
The process of burnishing shafts proposed here aims at increasing the service durability of marine pump shafts of seawater installations, which should give economic benefits in comparison with traditional methods. Burnishing process enables the achievement of high smoothness of machined surface together with the surface layer hardening. This process has been performed in industrial experience on universal machine tools and on CNC machines but it is regarded as plastic tooling. Therefore, the final formation of dimensions and service properties with the use of burnishing constitutes a chipless and dustless treatment, which allows for ranking burnishing among ecological tooling methods. The review of literature pointed out three fundamental purposes of the application of burnishing in the machine elements production process:

- smoothness tooling - which results in the reduction of the surface roughness after machining that precedes burnishing,

- strengthening tooling - which increases service properties (i.e. resistance to fatigue wear, abrasive wear and corrosive wear) by change of material properties in the surface layer, dimension-smoothness tooling - which increases the dimension accuracy with simultaneous reduction of surface roughness to its required value.

Burnishing process enables surface working at high dimensional precision (accuracy class 7 and 6) which makes it possible to achieve such advantages as [11-13]:

- ability to reach high surface smoothness $(\mathrm{Ra}=0.32-0.04 \mu \mathrm{m})$ and high bearing surface of roughness profile $(90 \%)$,

- increase of the surface hardness,

- increase of resistance to fatigue ( both surface and volumetric),

- increase of resistance to abrasive and mashing wear,

- lack of abrasive grit, sharp and hard built-up edge fragments and chips on burnished surface,

- ability to use burnish tools on universal lathes ( the concept of one stand working),

- elimination or reduction of the time consuming operations such as: honing, lapping, grinding and polishing,

- ability to eliminate heat treatment in certain cases,

- high process efficiency (one pass of a tool) and production costs reduction,

- high durability of burnishes,

- reduction of expenses related to machine parts production.

Numerous scientific centres all over the world deal with burnishing treatment and its impact on the surface layer. Research programmes usually cover issues related to burnishing of cast iron, some heat resisting alloys, stainless steel, copper and aluminium alloys, titanium and its alloys, composite and intermetallic coatings $[6,7]$ as well as parts produced by sintering metal powders.

The surface layer of material is specifically subjected to various degradable factors. However, it is not possible to avoid adverse phenomena of surface degradation during working conditions as well as corrosive influence of work environment. Therefore, the aim of the paper is to obtain proper technological quality and suitable service properties of angular momentum pump shaft pins applied to sea water systems in marine engines. Within the research, the optimization of burnishing technological parameters was carried out and the influence of the number of burnishing tool passes on the hardness and stereometric parameters of angular momentum pump shaft pins was defined. Therefore burnishing should be performed on account of the minimization of $\mathrm{R}_{\mathrm{a}}$ surface roughness factor as well as maximization of $S_{u}$ surface layer relative hardness degree. The article will present the results of the research on pins corrosive properties in the form of potentiodynamic examinations.

\section{Samples preparation}

The process of turning and burnishing of shaft pins $\phi 40 \mathrm{~mm}$ in diameter, made of X5CrNi 18 10 stainless steel was carried out on a universal CDS 6250 BX-1000 centre lathe. The preliminary lathing process was conducted by a cutting tool with WNMG 080408 WF removable plates by 
Sandvik Coromant. The super finishing Wiper plates ensure high efficiency of finishing and semi - finishing treatment. Properly designed geometry made it possible to apply two times more feed at the same surface finishing quality in comparison with traditional plates. Therefore during the preliminary lathing (Fig. 1a) the following machining parameters were used: machining speed $\mathrm{V}_{\mathrm{c}}=112 \mathrm{~m} / \mathrm{min}$, feed $\mathrm{f}=0.27 \mathrm{~mm} / \mathrm{rev}$, machining depth $\mathrm{a}_{\mathrm{p}}=0.5 \mathrm{~mm}$. The grinding process was performed by grinding attachment for lathes (Fig. 1b). The $1-80 \times 10 \times 32-99 \mathrm{C} 80-\mathrm{N}$ V grinding wheel was used for the process.

The process of burnishing (Fig. 1c) was conducted by SRMD one roller burnish by Yamato (Fig. 2). Within the research, the optimization of burnishing technological parameters was conducted on account of the minimization of Ra surface roughness coefficient as well as the maximization of $\mathrm{S}_{U}$ degree of surface layer relative hardness $[5,8,9]$. The multi criteria optimization conducted by min-max method [4] with regard to minimum surface roughness as well as maximum degree of surface layer hardness demonstrated that burnishing process should be carried out at the following technological parameters: burnishing force $1.1 \mathrm{kN}$, burnishing speed $35 \mathrm{~m} / \mathrm{min}$, feed $0.13 \mathrm{~mm} / \mathrm{rev}$. In addition, the influence of the burnisher passes number on the surface layer quality was determined [3]. The applied parameters of technological process of surface tooling were presented in Tab. 1. The research also covered the determination of the influence of burnish tool passes number on corrosive properties.

a)

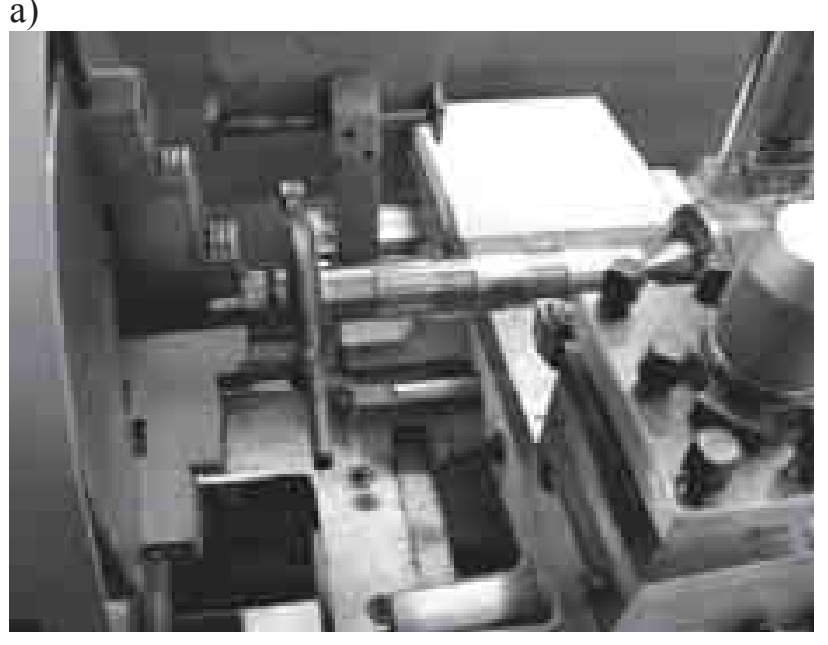

b)

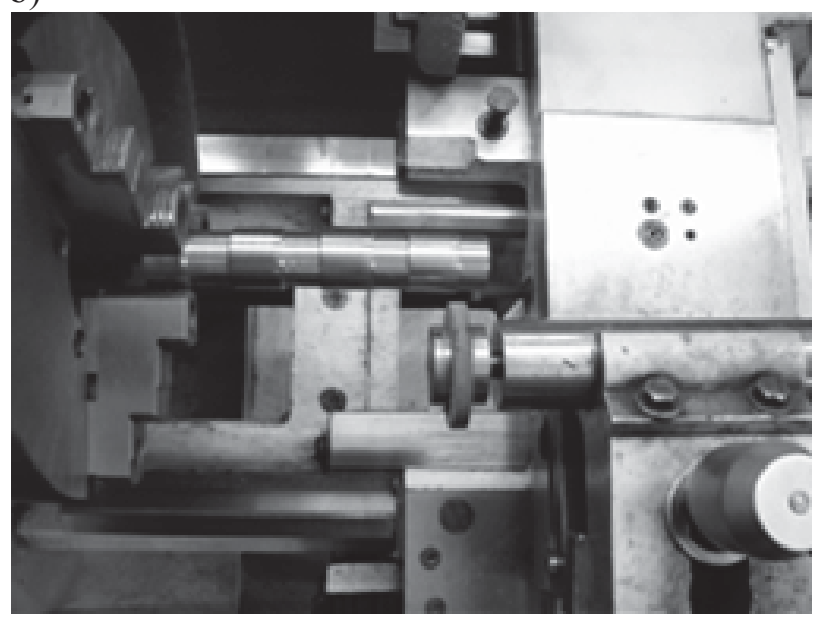

c)

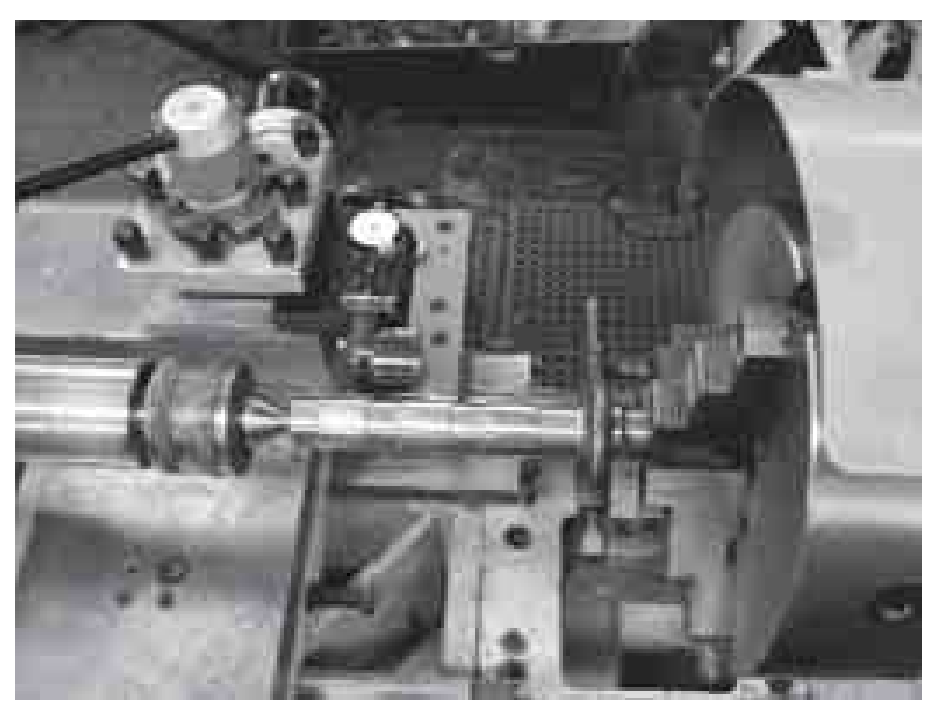

Fig. 1. The view of working assembly (machine tool, fixture, object, tool) - a) lathing c) grinding b) burnishing 


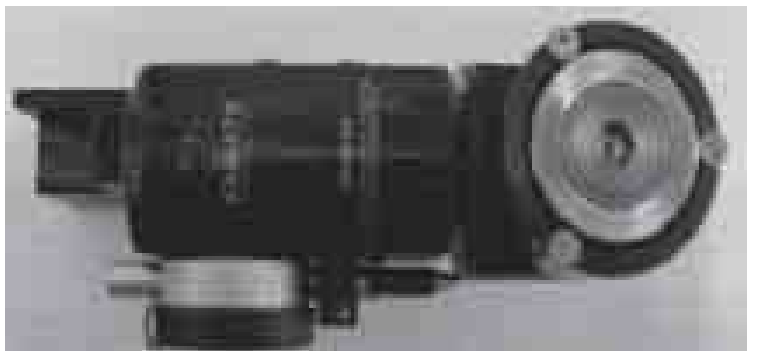

Fig. 2. Burnishing tool

Tab. 1. Technological parameters of burnishing process

\begin{tabular}{|c|c|c|}
\hline \multicolumn{2}{|c|}{ Parameter } & Values \\
\hline Burnishing force $-\mathrm{F}$ & {$[\mathrm{kN}]$} & 1.1 \\
\hline Burnishing speed $-\mathrm{V}_{\mathrm{n}}$ & {$[\mathrm{m} / \mathrm{min}]$} & 35 \\
\hline Feed $-\mathrm{f}$ & {$[\mathrm{mm} / \mathrm{rev}]$} & 0.08 \\
\hline
\end{tabular}

\section{Research methodology}

The measurement of corrosion resistance was performed by potentiodynamic method in a trielectrode system. The degreased sample with the area of $1 \mathrm{~cm}^{2}$ together with auxiliary (polarization) electrode made of plated titanium and reference electrode (calomel-saturated electrode) were immersed in a vessel containing substitute seawater (PN-66/C-06502). Before taking measurements, the samples were subjected to explosion in electrolyte in order to stabilize the corrosion potential. During measurement, the electrolyte was being mixed $[1,2,10,14]$.

The polarization curve was recorded in the range of $\pm 150 \mathrm{mV}$ of corrosion potential. Potential change rate, relating to all trials, was $10 \mathrm{mV} / \mathrm{min}$. The Atlas 0531 EU\&IA potentiostat was used to execute the examination. The estimation of corrosion process parameters was performed by Elfit 2 computer program.

\section{Research results}

The surface that is characterized by higher accuracy (by decreasing the height and the amount of surface roughness, by eliminating surface damages such as micro cracks and scratches) has a smaller corroding surface, which should improve its corrosion resistance. Whereas the non uniform appearance of internal hardening in the surface layer can cause the formation of galvanic microcells in the plastically deformed crystals, which can consequently promote corrosion. Therefore, the corrosion resistance of finishing tooling objects depends on two factors: the degree of cold work and surface smoothening. Higher resistance to corrosion can be achieved by the application of smoothness burnishing which is characterized by low cold work. This type of process comprises machining in which the SRMD one roller burnisher is the basic tool.

Table 2 presents the results of mean electrochemical potential values and corrosive currents density of the shafts examined for the potentiodynamic research. Fig. 7 shows exemplary polarization curves for samples cut off the shaft pins after burnishing. The analysis of the obtained results for corrosion currents density for particular samples demonstrated a slight improvement of resistance to corrosion of the burnished samples.

The average corrosion current density value for shaft pin surface after lathing was $0.8 \mu \mathrm{A} / \mathrm{cm}^{2}$. The burnishing caused almost $44 \%$ decrease of Jcor value that is $0.45 \mu \mathrm{A} / \mathrm{cm}^{2}$. Further burnisher passes allowed to decrease the average Jcor value of the corrosion current density three times $\left(0.25 \mu \mathrm{A} / \mathrm{cm}^{2}\right)$ when compared to lathing samples. The average corrosion current density value for shaft pin surface after grinding was $2.15 \mu \mathrm{A} / \mathrm{cm}^{2}$. That indicates that the sample, after grinding process, showed the lowest resistance to electrochemical corrosion. The results obtained testify the improvement of 
corrosion resistance of shaft pins, which were subjected to burnishing process. The effect was obtained by decreasing the surface roughness and consequently by decreasing the area of corroding surface.

The corrosion potential value for finish lathing, however, reached more favourable value $(\mathrm{Ec}=$ $-189 \mathrm{mV})$ in comparison to burnishing $(\mathrm{Ec}=-250 \mathrm{mV})$. Consecutive passes of a burnishing tool did not cause a distinct decrease of potential, and the difference amounting to $7 \mathrm{mV}$ lies within the standard deviation limit. The average corrosion potential value for shaft pin surface after grinding was $\mathrm{Ec}=-314 \mathrm{mV}$. The average corrosion potentials values obtained for samples after burnishing prove a higher susceptibility to corrosion. However, the values of corrosion current density were expressed in decimal parts $\mu \mathrm{A} / \mathrm{cm}^{2}$, so it can be assumed that for austenitic 304L steel - the resistance to electrochemical corrosion in seawater environment remains at the same level after application of lathing and burnishing.

Tab. 2. The results of potentiodynamic research

\begin{tabular}{|c|c|c|c|c|}
\hline Sample & $\begin{array}{c}\text { Corrosion potential } \\
\text { value Ec }[\mathrm{mV}]\end{array}$ & Standard deviation & $\begin{array}{c}\text { Corrosion current } \\
\text { density value } \\
\text { Jcor }\left[\mu \mathrm{A} / \mathrm{cm}^{2}\right]\end{array}$ & Standard deviation \\
\hline T roller & -189 & 5 & 0.80 & 0.10 \\
\hline S roller & -314 & 8 & 2.15 & 0.11 \\
\hline N roller & -250 & 5 & 0.45 & 0.10 \\
\hline 3N roller & -257 & 8 & 0.25 & 0.05 \\
\hline
\end{tabular}

a)

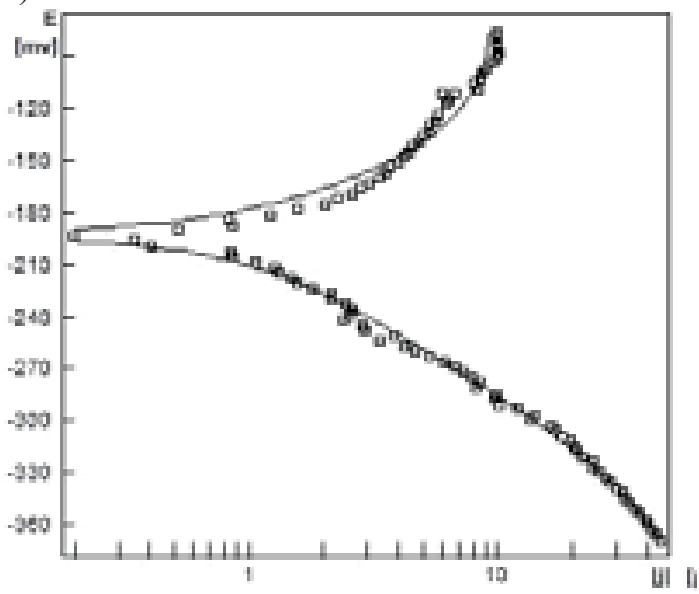

c)

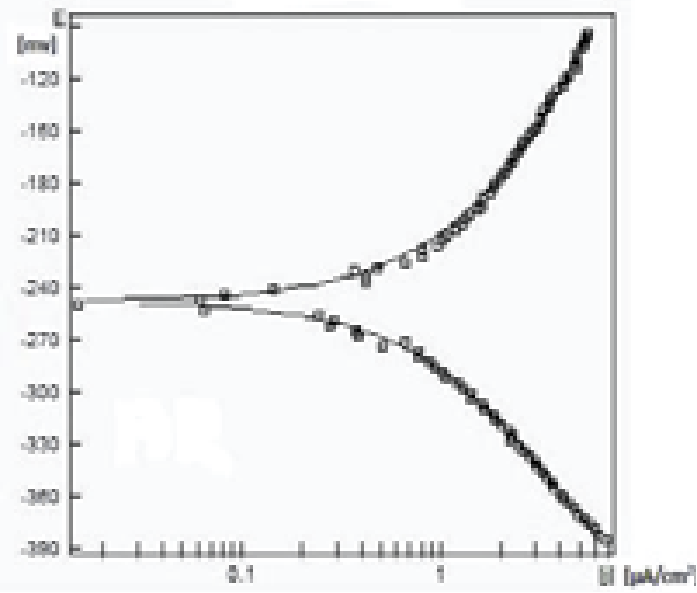

b)

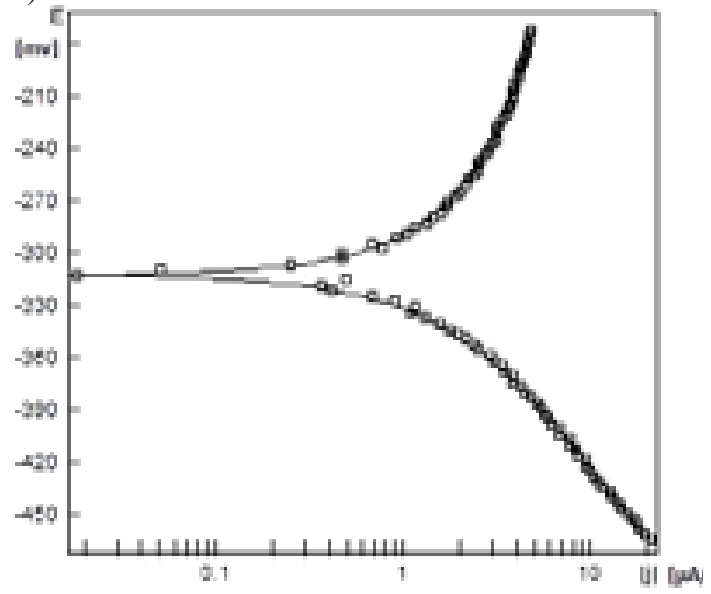

d)

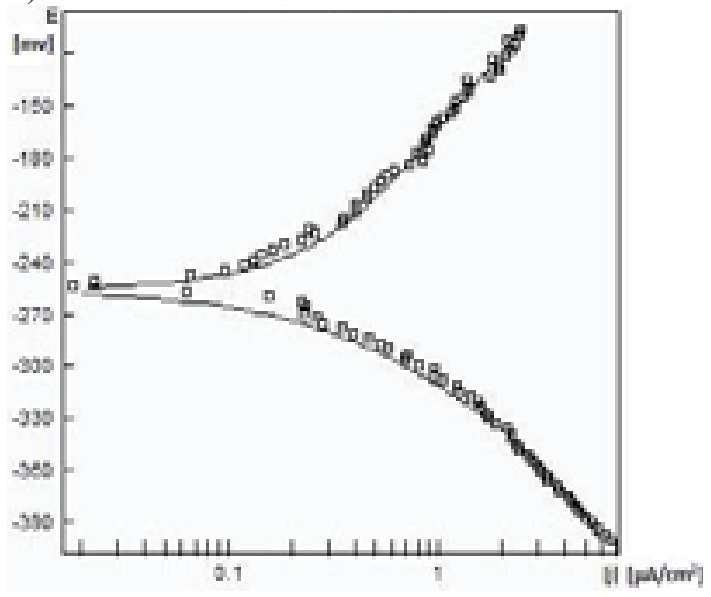

Fig. 3. Exemplary Tafel curves for rollers a) lathing, b) grinding c) after burnishing d) III passes of burnisher tool 


\section{Conclusions}

The process of burnishing of shaft pins resulted in the decrease of $\mathrm{R}_{\mathrm{a}}$ roughness parameter at the simultaneous increase of $\mathrm{S}_{U}$ surface layer relative hardness. Consecutive passes of a burnisher did not cause an additional surface hardening, but allowed to reach a surface of higher smoothness. Thus, the process of burnishing that was performed can be recognised as smoothness tooling. Marine pumps operating in seawater conditions are made of proper quality material being protective owing to its chemical composition. The corrosion current density results obtained for shaft pins after lathing and burnishing make it possible to state that burnishing process causes $44 \%$ increase of electrochemical corrosion resistance in seawater conditions when compared with lathing. They indicate that the sample, after grinding process, showed the lowest resistance to electrochemical corrosion.

\section{References}

[1] Bala, H., Korozja materiałów - teoria i praktyka, Wydawnictwo Wydziału Inżynierii Materiałowej i Fizyki Stosowanej Politechniki Częstochowskiej, Częstochowa 2002.

[2] Budniok, A., Łagiewka, E., Problemy elektrochemii w inżynierii materiałowej, Wydawnictwo Uniwersytetu Śląskiego, Katowice 2009.

[3] Charchalis, A., Starosta, R., Labuda, W., Estimation of the influence of burnishing tool passes number on ships pumps shafts surface layers strengthening and roughness changes, Journal of KONES Powertrain and Transport, Vol. 16, No. 4, pp. 43-50, Zakopane 2009.

[4] Charchalis, A., Starosta, R., Labuda, W., Multi-criteria optimalization of steel burnishing parameters applied to marine pumps shaft pins, Journal of KONES Powertrain and Transport, Vol. 17, No. 3, pp. 55-62, Jurata 2010.

[5] Charchalis, A., Starosta, R., Labuda, W., The influence of burnishing parameters on the roughness, plastic strain and shape deviations of marine pumps crankshaft pins in fresh water installations, Journal of KONBiN, No 1-2 (9,10). pp. 57-66, Warszawa 2009.

[6] Dyl, T., Skoblik, R., Starosta, R., The Effect of the Ceramic Dispersion on the Nickel Matrix Composite Coating Properties after Plastic Working, Solid State Phenomena, Vol. 147-149, pp. 813-818, Switzerland 2009.

[7] Dyl, T., Starosta, R., Skoblik, R., The effect of the unit pressure on the NiAl and Ni3Al intermetallic coatings selection parameters after plastic working. Solid State Phenomena, Vol. 165, pp. 19-24, Switzerland 2010.

[8] Labuda, W., Starosta, R., Estimation of the influence of burnishing parameters on X5CrNi18-10 steel, Solid State Phenomena, Trans Tech Publication, Vol. 165, pp 300 - 305, Switzerland 2010.

[9] Labuda, W., Starosta, R., Dyl, T., Estimation of the influence of burnishing parameters on steel X5CrNi1810 surface layers strengthening and roughness changes, Journal of KONES Powertrain and Transport, Vol. 15, No. 3, pp. 259-267, Warszawa 2008.

[10] Starosta, R., The influence of plastic strain on the corrosive properties of plasma sprayed intermetallic NiAl and Ni3Al coatings, Solid State Phenomena, Vol. 165, pp. 165-177, Switzerland 2010.

[11]Przybylski, W., Wpływ stanu warstwy wierzchniej konstytuowanej przez nagniatanie na trwałość elementów maszyn, Wybrane problemy Trybologii, PWN, Warszawa 1990.

[12]Przybylski, W., Współczesne problemy w technologii obróbki przez nagniatanie, Wydawnictwa Politechniki Gdańskiej, Gdańsk 2005.

[13]Przybylski, W., Współczesne problemy w technologii obróbki przez nagniatanie, Tom 2, Wydawnictwa Politechniki Gdańskiej, Gdańsk 2008.

[14] Trzaska, M., Trzaska, Z., Elektrochemiczna spektroskopia impedancyjna $w$ inżynierii materiałowej, Wydawnictwa Politechniki Warszawskiej, Warszawa 2010. 